\title{
Mucociliary function and nasal resistance evaluation before and after adenoidectomy
}

\author{
M. Maurizi, G. Paludetti, F. Ottaviani, G. Almadori and S. Falcetti \\ Institute of Otorhinolaryngology, University of Perugia (Italy) \\ (Received 6 January 1986) \\ (Revised version received 8 March 1986) \\ (Accepted 25 May 1986)
}

Key words: Adenoidectomy - Nasal mucociliary clearance - Rhinomanometry

\section{Summary}

Thirty-four children with clinically and radiologically confirmed adenoid hypertrophy underwent otoscopy, impedance tests, active anterior rhinomanometry and nasal mucociliary clearance evaluation before and 6 months after adenoidectomy. Mucociliary clearance velocity increased significantly while binasal resistances decreased after surgery. The authors conclude that mucociliary evaluation and objective measurements of nasal resistances should be added to impedance tests as indicators to adenoidectomy.

\section{Introduction}

Adenoidectomy represents the commonest surgical procedure in paediatric otolaryngology. While it undoubtedly enhances the nasal respiration, its effectiveness on secretory otitis media is still controversial. It is believed that nasal and rhinopharyngeal pathology can cause an eustachian tube dysfunction basically due to hyperpressure in the rhynopharynx and to a mechanical obstruction of the pharyngeal ostium of the tube, which are probably due to mucosal swelling, nasal discharge and reduced ciliary function $[14,15,34]$.

The aim of the present study is to objectively evaluate the influence of adenoidectomy on nasal airflow and on the nasal mucociliary function.

Correspondence: M. Maurizi, Istituto di Clinica Otorinolaringoiatrica, Via E. Dal Pozzo, I-06100 Perugia, Italy. 


\section{Materials and Methods}

Thirty-four children, 22 males and 12 females, aged between 5 and 7 years ( $M=6.6 \pm 1.9$ ), were examined. They were selected among a total of 78 children admitted to our clinic during the period March-May 1985 to undergo adenoidectomy. Children were randomly chosen among those living in Perugia and surroundings, as follow-up would have been easier. Clinical criteria consisted of severe nasal obstruction, rhinorrea, recurrent otitis media or long-standing otitis media with effusion. Posterior rhinoscopy was performed whenever possible and in unsuccessful cases a manual palpation was carried out. An adequate control group could not be collected, as all children with such signs underwent adenoidectomy. All children underwent impedance tests, active anterior rhinomanometry (AAR) and mucociliary clearance (MC) evaluation. Before performing AAR, all children were invited to blow their nose and crusts, if present, were manually removed. This test was performed before and $15 \mathrm{~min}$ after local application of nasal decongestants (Xylomethazoline, $7.5 \mathrm{mg}$ ). The same tests, in the same temporal sequence, were performed again 6 months after the operation.

AAR was performed by means of a 2-channel ICS Medical Cottle's rhinomanometer. Concerning pressure (P) and flow (V) calibration, each millimeter deflection of the pen corresponded, respectively, to $2 \mathrm{~mm} \mathrm{H}_{2} \mathrm{O}$, and 2 liter $/ \mathrm{min}$. Uninasal $(\mathrm{P} / \mathrm{V}$ ) and global $\left(R n_{\text {tot }}=R n_{1} \times R n_{r} / R n_{1}+R n_{r}\right)$ nasal resistances were calculated.

$\mathrm{MC}$ was evaluated calculating the time needed by saccharine crystals to reach the rhynopharynx, as this method has been demonstrated to be as reliable as the radioisotopic one [44]. It has been suggested, in a recent paper [40], to add charcoal powder to $3 \%$ saccharine, in order to increase information about the real mucociliary transport time. The length of the nasal cavity was measured by calculating the distance between the medial incisives and the soft palate inferior limit.

Both AAR and MC were performed at the same temperature and humidity conditions, in the same environment, at the same time and in the same head position.

The statistical evaluation of pre- and postoperative MC and AAR data was performed by means of the paired Student's $t$-test. Pre- and postoperative MC data were also compared to a control group of normal children previously tested in our laboratory [29], by means of the unpaired Student's $t$-test.

\section{Results}

\section{Nasal obstruction}

Nasal obstruction was present in $100 \%$ of children and mucopurulent rhinorrea in $20 / 34(64.7 \%)$. Tonsils were hypertrophied in $14 / 34(67 \%)$. Nasal symptoms improved in $32 / 34(92.3 \%)$ cases 6 months after the operation.

\section{Active anterior rhinomanometry}

The means values of uni- and binasal resistances before and after adenoidectomy 
TABLE I

ACTIVE ANTERIOR RHINOMANOMETRY (AAR): MEAN VALUES (M \pm 1 SD) OF PRE- AND POSTOPERATIVE UNI- AND BINASAL RESISTANCES

(A), basal condition; (B), post-decongestants; (BR), binasal resistances.

\begin{tabular}{|c|c|c|c|c|c|c|}
\hline & \multicolumn{3}{|c|}{ Pre-adenoidectomy values } & \multicolumn{3}{|c|}{ Post-adenoidectomy values } \\
\hline & Right & Left & Binasal & Right & Left & Binasal \\
\hline (A) & $3.3 \pm 3.1$ & $2.8 \pm 1.7$ & $1.1 \pm 0.5$ & $1.7 \pm 1.0$ & $1.8 \pm 0.9$ & $0.8 \pm 0.3$ \\
\hline \multirow[t]{3}{*}{ (B) } & $1.6 \pm 1.0$ & $1.8 \pm 1.5$ & $0.8 \pm 0.4$ & $1.3 \pm 0.9$ & $1.4 \pm 1.0$ & $0.6 \pm 0.3$ \\
\hline & \multicolumn{3}{|c|}{$\begin{array}{l}\text { BRA-Pre vs BRB-Pre } P \leqslant 0.001 \\
\text { BRA-Pre vs BRA-Post } P \leqslant 0.001\end{array}$} & \multicolumn{3}{|c|}{ BRA-Post vs BRB-Post $P \leqslant 0.01$} \\
\hline & \multicolumn{3}{|c|}{ BRA-Pre vs BRA-Post $P \leqslant 0.001$} & \multicolumn{3}{|c|}{ BRB-Pre vs BRB-Post $P \leqslant 0.01$} \\
\hline
\end{tabular}

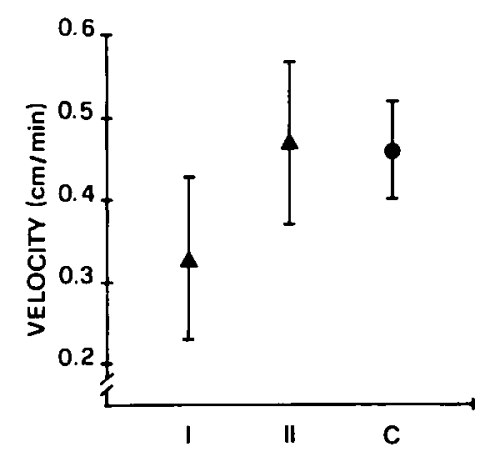

Fig. 1. Pre (I)- and postoperative (II) nasal mucociliary velocity values. Postoperatively, a statistically significant increase $(P \leqslant 0.001)$ can be observed, almost reaching control values $(C)$.

are represented in Table I. Global nasal resistances decreased postoperatively from $1.1 \pm 0.6$ to $0.8 \pm 0.3 \mathrm{~mm} \mathrm{H}_{2} \mathrm{O} /$ liter $/ \min (P \leqslant 0.001)$ (Table I). A similar decrease could be observed after administration of nasal decongestants both before $(P \leqslant$ $0.001)$ and after $(P \leqslant 0.01)$ adenoidectomy, and comparing pre- and postoperative data (Table I).

\section{Mucociliary clearance}

The mean values of mucociliary transport velocity were $0.33 \pm 0.10 \mathrm{~cm} / \mathrm{min}$ before adenoidectomy and $0.47 \pm 0.11 \mathrm{~cm} / \mathrm{min}$ after, a statistically significant increase being therefore present $(P \leqslant 0.001)$ (Fig. 1). Postoperative data almost overlap controls (Fig. 1).

\section{Discussion}

The obtained data confirm that in children affected by adenoid hypertrophy an impairment of mucociliary function can be detected, partly due to the mechanical obstruction and to the consequent mucous retention [45], partly to the chronic 
sufferance of the ciliary component of the respiratory mucosa. In fact a marked loss of cilia, reaching sometimes squamous metaplasia, which is directly related to the lymphoid tissue size, has been observed in a previously published paper [29].

Concerning rhinomanometry $[7,11,12,33]$, although this technique has been widely employed in clinical practice, only a few reports can be found in the literature about children $[9,21,27,33,41,43,56]$. High nasal resistances have been demonstrated to influence, also in children, the lower airways function [36]. It has also been shown that an obstructive type of ventilatory defect can be detected in adenoid hypertrophy children $[10,28,56]$. Van Cauwenberge [55] observed that children aged between 3 and 6 years do not have an alternating nasal cycle as normal adults, but that important fluctuations of the nasal resistance in the left and right nasal cavity are happening in the same sense, lasting almost $57 \mathrm{~min}$ ('solidaly cycle'). As in adults, physical exercise, body position and nasal pathology can influence nasal resistance [56]. Furthermore, it has been observed [56] that in children with nasal pathology, nasal resistances are higher than in those without any pathology. The same author recommends, due to the large standard deviations of nasal resistance values in pathological conditions, to carefully interpret the results of a one time rhinomanometrical measurement. On the other hand, Principato and Wolf [43] found that in childhood nasal resistance values vary inversely with age and fall in an almost linear fashion between already established normals of infancy and adulthood.

In the present study we ruled out most of the variables induced by spontaneous and evoked changes by using nasal decongestants. It has been experimentally proven that if nasal obstruction is caused by adenoid hypertrophy, it does not significantly decrease after local decongestants administration $[27,33]$.

It has also been demonstrated that rhinomanometry, if correctly used, yields interesting informations concerning results of surgical procedures on nasal and nasopharyngeal structures $[8,21,42]$. Our data clearly show that binasal resistances increase, due to adenoid hypertrophy, and that they decrease after adenoidectomy $[21,23,50]$.

While some authors believe adenoidectomy to be effective in the treatment of OME $[1,2,5,20,24-26,30-32,35,37,38,53]$, some others, instead, suggest that adenoidectomy yields unpredictable results [4], or is uneffective on OME patients $[19,25,39,46,47]$. Many variables seem to interfere with an accurate evaluation of the real effectiveness of adenoidectomy on OME, and they include age [26,30,51], sex $[6,13,16,17]$, nasal obstruction $[3,47,49]$, eustachian tube function $[3,4,39]$ and, mainly, the high rate of spontaneous recovery of OME, especially in warmer seasons $[18,52,54,55]$.

The aim of the present paper is to stress the significant postoperative enhancement of the mucociliary transport and the significant reduction of the nasal resistances. It appears, then, to be reasonable to operate upon children with severe and objectively detected long-standing nasal obstruction, persistent purulent rhinorrea, recurrent adenoiditis and reduced mucociliary function. On the other hand, an accurate and objective evaluation of such parameters by means of AAR and MC transport evaluation, appears to be advisable prior to the operation. 


\section{References}

1 Ballenger, S.S., Diseases of the Nose, Throat and Ear, Lea \& Fabinger, Philadelphia, 1969.

2 Bateman, G.H., Secretory otitis media, J. Laryngol. Otol., 71 (1957) 261.

3 Bluestone, C.D., Cantekin, E.I. and Berry, Q.C., Certain effects of adenoidectomy on Eustachian tube ventilatory function, Laryngoscope, 85 (1975) 113.

4 Bluestone, C.D. and Berry, Q.C., Adenoidectomy in relation to otitis media, Ann. Otol. Rhinol. Laryngol., Suppl. 25 (1976) 280.

5 Botsic, W.P., The role of adenoidectomy in secretory otitis media. In S.B. Snow (Ed.), Controversy in Otỏlaryngology, Saunders, Philadelphia, 1980.

6 Brooks, D.N., School screening for middle ear effusion, Ann. Otol. Rhinol. Laryngol., 25 (1976) 223.

7 Broms, P., Rhinomanometry, Thesis, Lund, 1980.

8 Broms, P., Jonson, B. and Malm, L., Rhinomanometry. IV. A pre- and post-operative evaluation in functional septoplasty, Acta Otolaryngol., 94 (1982) 523.

9 Clement, P.A.R. and Daele, S.S., Some statistical data about anterior rhinomanometry, Rhinology, 18 (1980) 151.

10 Collier, A.M., Pimmel, R.L., Hasselblad, V., Clyde, N.A., Knelson, S.H. and Brook, J.G., Spirometric changes in normal children with upper respiratory infections, Am. Rev. Resp. Dis., 117 (1978) 47.

11 Cottle, M.H., Rhino-sphygmo-manometry: an aid in physical diagnosis, 1 (1963) 23.

12 Crifo, S., Saponara, M., Cittadini, S, De Seta, E. and D'Ascanio, G.F., Rino-reomanometria clinica. I: i valori nel normale, Boll. Soc. Ital. Biol. Sper., 51 (1975) 420.

13 Davison, F.W., Prevention of recurrent otitis media in children, Ann. Otol. Rhinol. Laryngol., 75 (1966) 735.

14 Dawes, J.D.K., The aetiology and sequelae of exudative otitis media, J. Laryngol. Otol,, 84 (1970) 583.

15 De Weese, D.D. and Saunders, W.H., A textbook of otolaryngology, Mosby, St. Louis, 1973.

16 Draper, W.L., Secretory otitis media in children: a study of 540 children, Laryngoscope, 77 (1967) 636.

17 Eagle, E., Secretory otitis media, Ann. Otol. Rhinol. Laryngol., 55 (1946) 55.

18 Fiellau-Nikolajsen, M., Tympanometry in 3-year-old children. Prevalence and spontaneous course of MEE, Ann. Otol. Rhinol. Laryngol., Suppl. 68 (1980) 223.

19 Fiellau-Nikolajsen, M., Tympanometry and secretory otitis media, Acta Otolaryngol., Suppl. 394 (1983).

20 Gottschalk, G.H., Serous otitis. A conservative approach to treatment, Arch. Otolaryngol., 96 (1972) 110.

21 Jessen, M. and Malm, L., Longterm follow-up of patients with nasal stuffiness and normal NAR, Acta Otolaryngol., Suppl. 214 (1984) 95.

22 Linder-Aronson, S. and Bäckström, A., A comparison between mouth and nose breathers with respect to occlusion and facial dimensions, Odont. Rev., 11 (1960) 343.

23 Linder-Aronson, S., Adenoids: their effect on mode of breathing and nasal airflow and their relationship to characteristics of the facial skeleton and the dentition, Acta Otolaryngol., Suppl. 265 (1970) 1.

24 Lous, J. and Fiellau-Nikolajsen, M., Epidemiology of middle ear effusion and tubal dysfunction. A one year prospective study comprising monthly tympanometry in 387 non-selected seven-year-old children, Int. J. Ped. Otorhinolaryngol., 3 (1981) 303.

25 Marshak, G. and Neriah, Z.B., Adenoidectomy versus tympanotomy in chronic secretory otitis media, Ann. Otol., Suppl. 68 (1980) 316.

26 Martini, A., Guastella, G., Andolfo, F.M. and Molinari G., Effetti dell'adenoidectomia sulla funzionalità dell'orecchio medio: follow-up ad un anno mediante timpanometria, Acta Otorhinolaryngol. Ital., 4 (1984) 139.

27 Masing, H., Laacke, R. and Leykanf, R., Nasal pressure flow studies in adults and children, Rhinology, 12 (1974) 137.

28 Maurizi, M., Paludetti, G., Todisco, T., Dottorini, M. and Grassi, V., Pulmonary function studies in adenoid hypertrophy, Int. J. Pediat. Otorhinolaryngol., 2 (1980) 243. 
29 Maurizi, M., Ottaviani, F., Paludetti, G., Almadori, G. and Zappone, E., Adenoid hypertrophy and nasal mucociliary clearance in children. A morphological and functional study, Int. J. Pediat. Otorhinolaryngol., 8 (1984) 31.

30 Maw., R.A., Chronic otitis media with effusion and adenotonsillectomy. a prospective randomized controlled study, Int. J. Pediat. Otorhinolaryngol., 6 (1983) 239.

31 McKee, W.J.E., A controlled study of the effects of tonsillectomy and adenoidectomy in children, Br. J. Rev. Soc. Med., 17 (1963) 49.

32 McKee, W.J.E., The part played by adenoidectomy in the combined operation of tonsillectomy with adenoidectomy; second part of a controlled study in children, Br. J. Rev. Soc. Med., 17 (1963) 133.

33 Melon, J. and Daele, J., Les explorations fonctionnelles et endoscopiques en rhinologie, Acta Otorhinolaryngol. Belg., 33 (1979) 639.

34 Mygind, N., Nasal Allergy, Blackwell Scientific, Oxford, 1979.

35 Nauman, H.H., Kopf und Hals Chirurgie, George Thieme, Stuttgart, 1974.

36 Ogura, S.H. and Harvey, J.E., Nasopulmonary mechanics; experimental evidence of the influence of the upper airway upon the lung, Acta Otolaryngol., 71 (1971) 123.

37 Palva, T., Raunio, V. and Nousianen, R., Secretory otitis media protein and enzyme analysis, Ann. Otol. Rhinol. Laryngol., Suppl. 11 (1974) 35.

38 Paparella, M.M. and Shumrick, W.H., Otolaryngology, Saunders, Philadelphia, 1973.

39 Paradise, J.L., Rogers, K.D., Bluestone, C.D. and Taylor, F.H., Efficacy of adenoidectomy in recurrent otitis media. Historical overview and preliminary results from a randomized controlled trial, Ann. Otol. Rhinol. Laryngol., Suppl. 68 (1980) 319.

40 Passàli, D., Bellussi, L., Bianchini Ciampoli, M. and De Seta, E., Experiences in the determination of nasal mucociliary transport, Acta Otolaryngol., 97 (1984) 319.

41 Polgar, G. and Kong, G.P., The nasal resistance of newborn infants, J. Pediat,, 67 (1965) 557.

42 Pozzi, G. and Corti, A., Studio rinomanometrico pre- e postoperatorio nella chirurgia conservativa dei turbinati inferiori, Comm. LXX Congr. Soc. Naz. S.I.O. e Ch. C.F., Bologna, Italy, 1983.

43 Principato, J.J. and Wolf P., Pediatric nasal resistance, Laryngoscope, 95 (1985) 1067.

44 Puchelle, E., Aug. F., Fham Q.T. and Bertrand, A., Comparison of three methods for measuring nasal mucociliary clearance in man, Acta Otolaryngol., 91 (1981) 297.

45 Reimer, $\AA$., Mecklemburg, von C. and Toremalm, N.G., The mucociliary activity of the upper respiratory tract. III. A functional and morphological study on human and animal material with special reference to maxillary sinus diseases, Acta Otolaryngol., Suppl. 355 (1978) 1.

46 Roydhouse, N., Adenoidectomy for otitis media with mucoid effusion, Ann. Otol. Rhinol. Laryngol., Suppl. 68 (1980) 312.

47 Rynnel-Dagöö, B., Ahlbom, A. and Schiratzki, H., Effects of adenoidectomy. A controlled two-year follow-up, Ann. Otol. Rhinol. Laryngol., 87 (1978) 272.

48 Samyal, M.A., Henderson, F.W., Stempel, E.C. et al., Effect of upper respiratory tract infection on eustachian tube ventilatory function in the pre-school children, J. Pediatr., 97 (1980) 11.

49 Snow, R.A., Chronic otitis media with effusion and adenotonsillectomy in the management of children with middle ear effusion, Ann. Otol. Rhinol. Laryngol., Suppl. 68 (1980) 43.

50 Stoksted, P., Rhinometric examination of school children with adenoid vegetations, Acta Otolaryngol., 39 (1951) 44.

51 Teele, D., Klein, S. and Rosner, B., Epidemiology of otitis media in children, Ann. Otol. Rhinol. Laryngol., Suppl. 68 (1980) 5.

52 Thomsen, J. and Tos, M., Spontaneous improvement of secretory otitis. A long term study, Acta Otolaryngol., 92 (1981) 493.

53 Tos, M., Poulsen, G. and Hancke, A.B., Screening tympanometry during the first year of life, Acta Otolaryngol., 88 (1979) 388.

54 Tos, M., Strangerup, S.E., Holmsensen, S. and Sorensen, C.H., Spontaneous course of secretory otitis and changes of the eardrum, Arch. Otolaryngol., 110 (1984) 281.

55 Van Cauwenberge, P. and Delaye, L., Nasal cycle in children, Arch. Otolaryngol., 110 (1984) 108.

56 Van Cauwenberge, P., De Schynkel, K. and Kluyskens, P.M., Clinical use of rhinomanometry in children, Int. J. Pediat. Otorhinolaryngol., 8 (1984) 163. 